\title{
Dayak Culture Aesthetic in the Interior Design Balanga Museum
}

\author{
Ika Yuni Purnama ${ }^{1}$
}

\author{
${ }^{1}$ Doctoral Student of Semarang State University, Faculty of Art and Design Jakarta Institute of Arts, Jakarta, Indonesia \\ *Corresponding author.Email: ikayuni@senirupaikj.ac.id
}

\begin{abstract}
This research is In 2012 the government revitalized the Ethnographic Museum of Balanga, the interior layout created following the atmosphere of traditional Dayak tribal life. Collections are organized based on the life cycle, starting from the ceremonies of the birth, marriage and final stages of the ceremony, namely the uniqueness of the Tiwah ceremony. Here there are also unique traditional weapons such as Chopsticks, Duhung, Mandau, miniature long houses called Betang, fish invitations called Mihing, Sapundu and Hampatung Karuhei statues, Turtle charms, various brassware, various Chinese ceramic jars from the Ming dynasty and Ching called Balanga and Malawen dishes. The Balanga Museum also received around one thousand confiscated weapons which were used during the ethnic conflict in Sampit in 2001 as a historical collection. The purpose of this study was to obtain data on the forms of interior layout related to the history of Dayak cultural life, so as to increase the knowledge and preservation of the interior design of the Balanga Museum as a cultural heritage that presents traditional Dayak tribal culture in Central Kalimantan.The researcher articulated, elaborated the characteristics of art objects, and explored in detail the use of color in showroom. The researcher used qualitative and semiotic methods.
\end{abstract}

Keywords: Dayak culture, interior design, Balanga museum

\section{INTRODUCTION}

The Balanga Ethnographic Museum is a museum located in Palangka Raya City, Central Kalimantan province, Indonesia. The Balanga Museum is located on Tjilik Riwut, only about $2.5 \mathrm{~km}$ from the Big Roundabout in the middle of the city of Palangkaraya in 1973 and was established by the Central Kalimantan regional government as a regional museum. In line with the central government's policy that each province has a museum that displays the uniqueness of local culture and natural wealth, in 1990 the Balanga Museum became a provincial museum and had various types of collections of material cultural products (cultural objects) grouped into collections of ethnography, history, archeology, chemistry, and numismatics. While natural objects are grouped into biology and geology collections. Based on data from the Culture and Tourism Office of Central Kalimantan Province, the collections at the Balanga Museum are divided into 10 object classifications, namely: Geology (188 collections); Biology (40 collections); Ethnographic (1,383 collections); Archeology (112 collections); History (1,116 collections); Numismatics (781 collections); Philology (4 collections); Ceramiclogica (572 collections); Fine art (5 collections); Technology (53 collections). The interior of the Balanga museum is an important part of the museum if it is said to be a preserver of the nation's culture. [1] In general, the museum exhibits include objects related to the history of Dayak culture in Central Kalimantan. The study aims to answer three questions, namely: (1) How does the museum's interior aesthetics relate to ethnography of Dayak culture? (2) How are interior spaces building an image of the importance of Dayak culture in lay out visualization, material processing, graphics, information, color, lighting, arrangement of objects, and other aesthetic elements?

The narrative line for the arrangement on the ground floor of the Balanga museum is a sequence of traditional Dayak life stories. The collection is arranged based on the life cycle, starting from the ceremonial equipment of the phases of birth, marriage and death. Events about the life cycle, which marks a life process from birth to death. The life cycle stage is marked through the life cycle ceremony stages. After that, the entry of new beliefs (Islam, Christianity) and the entry of the education system, literacy and medicine.

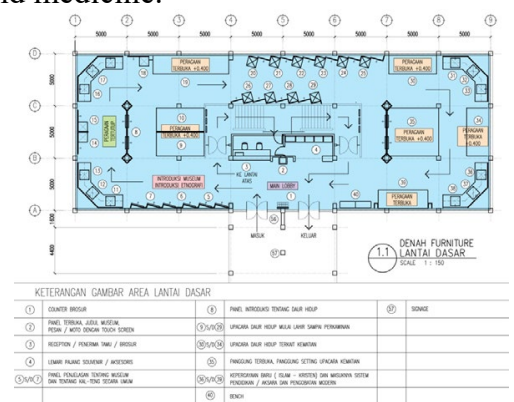

Figure 1 lay out Balanga Museum. Foto : Ika Yuni Purnama 


\section{RESEARCH METHOD}

The research will use a multidisciplinary approach to be able to produce a comprehensive analysis. This research is a qualitative study, which aims to map the interior of the ethnographic museum and the development of museum design in connection with the rapid development of design and technology. The collection of literature data in this study uses a survey of reading books relating to the spatial museum, trends in the presentation of the collection and its application in the ethnographic museum space, especially the Balanga Museum in Central Kalimantan. Other primary sources in the form of information obtained from interior design and museum books, design journals, interior design magazines and architects, articles written by scientists relating to the topic to be examined. To observe the interior of the museum requires literature and field observations. To get information from field sources by making direct observations to the Balanga Museum in Central Kalimantan and interviews with surviving sources and their managers. [2]

The Balanga museum collection is a traditional historical object that is used as a medium for narrative information lines on the life of the Dayaks in Central Kalimantan. The collection is then interpreted imaginatively and narratively to display the aesthetic value and communicative aspects. Interior designers in making the theme of the exhibition space pay attention to every tendency of human behavior in seeing a visual display. Collection objects and human behavior are the basic references of a space concept of a museum showroom. Interpretation is the act or process of explaining or classifying, translating or presenting a personal understanding of subject or object [3].

\section{DISCUSSION}

\subsection{The History of the Balanga Museum}

Palangka Raya is the capital of Central Kalimantan which has a lot of past cultures that originate from its original majority population, the Dayak tribe. Material culture is a relic art object that we can see visually such as: typical Dayak weapons, Dayak musical instruments, traditional Dayak houses and so on. While non-material culture in the form of literary works, dance, music, and so on. But at this time, the Dayak culture in Central Kalimantan has begun to experience extinction due to lack of preservation and attention from the community and government. In the city of Palangka Raya there is a museum, the Balanga Museum. The Balanga Museum was founded on April 6, 1973. The Balanga Museum was revitalized in 2013, now operating as it should be an ethnographic museum. This museum has been frequented and even visited by local visitors and foreign tourists. This is because the Balanga museum building looks attractive, and clean. The Balanga Museum has a duty as an educational development for the Dayak tribe in Central Kalimantan, among others collecting and documenting cultural objects (artifacts) and natural resources, procuring and converting cultural objects to display, and presenting cultural objects so can attract the public's interest to visit this museum, so that it can function as a place for cultural education, research and also study tours. Balanga Museum is a museum located in the capital of Central Kalimantan, namely the City of Palangka Raya, precisely on Jalan Tjilik Riwut KM 2.5. This museum was originally a National Council Monument Building (GMDN) which was built in 1963 and inaugurated on April 6, 1973 under the name "Balanga". The Director General of Education and Culture GVH Vooger inaugurated the museum to become the State Museum of the Central Kalimantan Province "Balanga", which later became the UPT. Central Kalimantan Museum "Balanga" under the guidance of the Culture and Tourism Office of Central Kalimantan Province. The Central Kalimantan Provincial Museum "BALANGA" was inaugurated on November 26, 1990 by GBPH Poeger, Director General of Culture at the Ministry of Education and Culture at that time. The construction of this museum has been pioneered since 1973 by the Central Kalimantan Regional Government I, under the name Balanga Museum. At that time the function of the Museum was still very limited with a limited collection as well. The collection items collected at that time were mostly ceramic, including jars (Ngaju Dayak Language = Balanga). In 1977 the Central Government through the Directorate General of Culture of the Ministry of Education and Culture conducted a feasibility study to establish a provincial state museum in Central Kalimantan. Ten years later (1987), through Minister of Education and Culture Decree Number 0754/0/1987, the government established the Balanga Museum as the State Museum of Central Kalimantan Province under the auspices of the Ministry of Education and Culture's Directorate General. Then it now stands under the auspices of the Culture and Tourism Office of Central Kalimantan Province. Central Kalimantan Provincial Museum "Balanga" in the context of service to museum visitors and the public has several facilities including: Pendopo, Administration Room, Auditorium and Educator Room, Library, Laboratory, Curator Room and Space, Collection Study, Generator Room, Temporary Exhibition Room , Permanent Exhibition Room, Head House, Gate of Guardhouse, Vehicle Pool. "Balanga" Museum also has a collection of books of various types including: Public Works, Social Sciences, Technology, Art and Sports, Literature. [4]

\subsection{Area of daily life of the Dayak}

Interior arrangement of the Balanga museum is based on narrative lines that are built from the history of the daily life of the Dayaks. The interior of the museum is also a unity of the order of the management of Balanga museum collection of objects consisting of historic traditional objects from the Dayak community life in Central Kalimantan. Spatial planning is grouped according to life cycle, starting from the ceremonial equipment for the 
phases of birth, marriage and death. In the museum there are also traditional weapons such as Chopsticks, Duhung, and Mandau. For a very typical collection of examples of residential buildings, for example, is a miniature longhouse called the Betang house. When you enter the exhibition hall, you will feel the atmosphere of traditional Dayak life. The collection is arranged according to the life cycle, starting from the ceremonial equipment of the phases of birth, marriage and finally death.

In the presentation of daily life stories the Dayak people are represented by presenting a graphic form of a wall with some objects which are a means of supporting daily life such as boats and weapons for hunting and fishing because Kalimantan is cut by many long and wide rivers and many tributaries, which are used as a transportation highway. In Central Kalimantan live Dayak Ngaju, Lawangan, Ma'anyandan Ot Danum, known as Dayak Barito, named after the Barito river. Among them the most dominant is Ngaju, which inhabits the Kahayan watershed with the current city of Palangkaraya. Ngaju is involved in agricultural trade, growing rice, cloves, coffee, palm oil, pepper and cocoa, while other tribes still practice subsistence farming through slash and burning. Although many Dayaks have been modernized and converted to Christianity and Islam, the majority still adhere to the original Kaharingan belief, also known as Hindu-Bali Kaharingan, which the state recognizes as a belief.
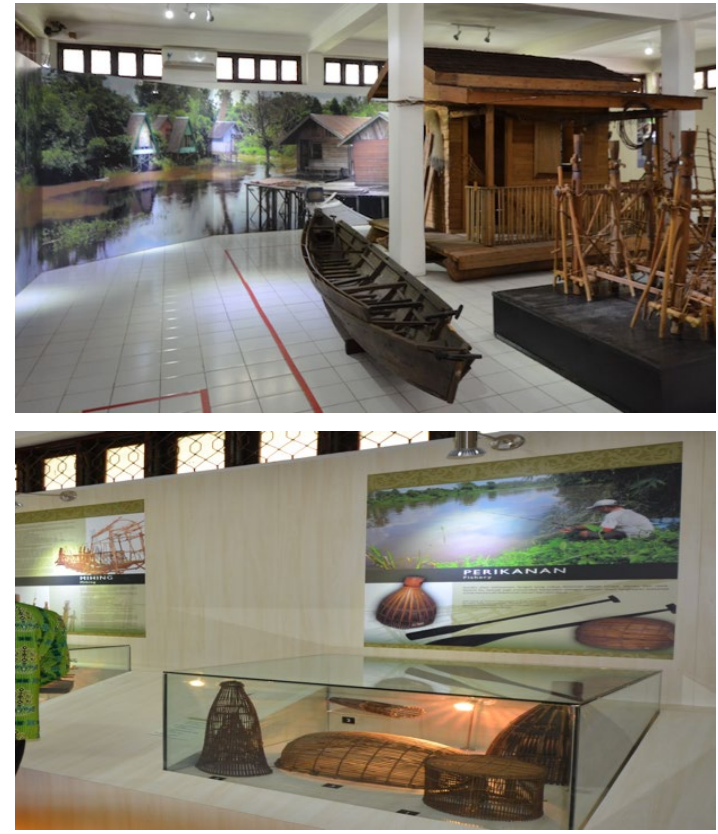

Figure 2 Area of daily life of the Dayak people.

\subsection{Area of the Dayak birth ceremony}

The Ngaju Dayak community believes that pregnancy requires special measures. The ritual is performed when a positive mother is pregnant and when the womb is three months, seven months and nine months. Ritual for three months of pregnancy is called Paleteng Kalangkang Sawang, as a sign of a request for delivery to proceed normally, a coil-like stagen made of brass containing beads and wrapped around the mother's waist. The ritual requirements for all ages of the womb are date animals (chickens and pigs), beads for ehet, fishponds, behavior, bananas, offerings and lilis beads and manas for attachment to pregnant women in order to ensure that pregnant mothers are not disturbed by evil spirits from the water. The seven-month gestational age ritual is called Nyaki Ehet or Nyaki Dirit, whose essence is to choose which ancestors will accompany and protect the mother and child in her birth. Then the ritual at the age of nine months of pregnancy is called the Mangkang Kahang Rhino, aiming for the baby not to be born prematurely. For the birth procession there is a unique process in which the mother's body is tilted, her head at the top and her legs at the bottom. The mother was laid in a place called Sangguhan. Officers who assist in the delivery process are usually village midwives or shamans. Completeness of the birth process in the form of; where the placenta / Tabuni damage, umbilical cord cutters / Sembilu, the place of delivery / Refraction Manak, the place of clothing / Saok, a place to store hot water, paraffin, a place for bathing babies / Kandarah, etc

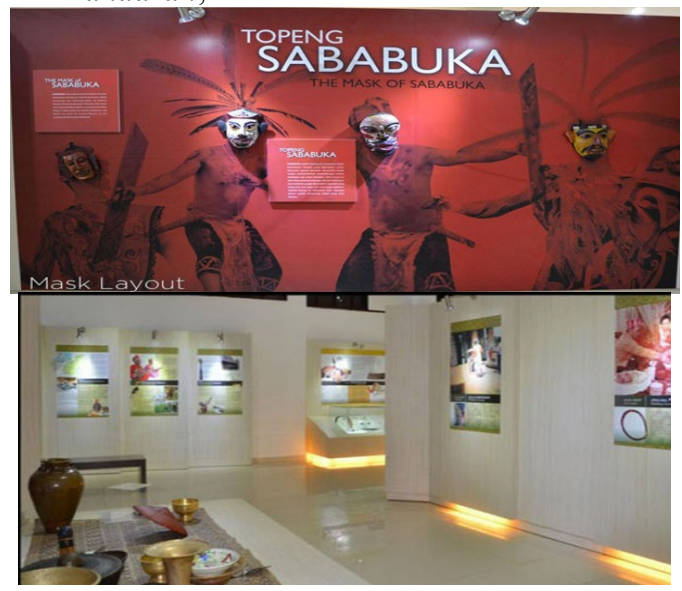

Figure 3 Area of the Dayak birth ceremony

\subsection{Area of the Dayak Wedding ceremony}

Since the entry of Christianity, which came together with Dutch colonialism, many Dayak Ngaju residents who were originally Kaharingan were baptized to become Christians. Accordingly, many traditions in the original Dayak religion experienced changes and shifts because of the influence of Christian teachings. One of the Dayak religious traditions that is affected is the marital procedures which are then considered customary and can be carried out by Dayak tribes who are no longer Hindu Kaharingan by negating some of the marital procedures which are related to the beliefs of the Hindu Kaharingan community of the Dayak Ngaju tribe, the Manyaki Malas Panganten ceremony (inauguration of marriage). Basically the Ngaju Dayak community's marriage ritual is formed 
from several parts that have been patterned in a single whole consisting of Hakumbang Auh (engagement), Hisek (determining the date of the marriage and the requirements / Hadat Road and marriage agreement), Mamanggul, Mananggar Promises the implementation of the Ceremony Marriage, such as Hasaki Hapalas (inauguration of marriage according to the procedures that have been handed down by the ancestors of the Dayak Ngaju tribe). Ranying Hatalla / God Almighty revealed His teachings through King Uju Hakanduang to carry out a marriage ritual for the King Garing Hatungku with Kamelus Endas Bulau Oral Tingang and in the marriage of Manyamei Tunggul Garing Janjahunan Laut with Kameluh Putak Bulau Janjulen Karangan, which both of these people according to the beliefs of the Kaharingan Hindu community were the forerunners of the first humans. Basically, this study is presented in spatial planning and presentation in the exhibition area with an understanding and meaning in the form of posters and graphic information as well as in the selection of the overall color of the area. [5]

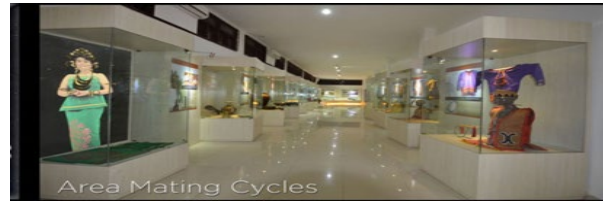

Figure 4 Area of the Dayak wedding ceremony

\subsection{Area of the Dayak Death ceremony}

In the myth of the Dayak Ngaju tribe, humans did not initially know death. That is because worldly life is something that is eternal. However, one-day humans make mistakes and finally eternal worldly life revoked by the gods. Humans who die will continue their journey to the world of the spirits. Humans who have changed form into spirits are called Lio / Liau / Liaw. Liau by the Dayak community must be escorted to the world of spirits, namely the highest nature called Lewu Liaw or Lewu Tatau. The uniqueness of the Tiwah or Tiwah Lale or Magah Salabung Liau Uluh Matei ceremony is a death ceremony performed by the Dayak Ngaju tribe in Central Kalimantan. The Tiwah ceremony itself is the largest sacred ceremony in the Dayak Tribe. That is because the Tiwah ceremony involves a lot of resources and quite a long time. The tiwah ceremony was conducted aiming to deliver the soul or spirit of a deceased human to the destination, namely Lewu Tatau Dia Rumpang Bones, Rundung Raja Dia Kamalesu Uhate, Lewu Tatau Habaras Bulau, Habusung Hintan, Hakarangan Lamiang or Lewu Liau located in the seventh heaven. . In addition, in the belief of Dayak Ngaju, the spirits of people who have not been escorted through the Tiwah ceremony will always be in the vicinity of the living human environment. Their presence is considered to bring disruption in the form of the emergence of crop failure events, diseases, and other dangers. The Tiwah ceremony in the Dayak Ngaju community is a social symbol of a person or family. The more lively and long duration, the higher one's social status. For families who have wealth, the Tiwah ceremony can be carried out independently ie only with his own family and carried out as soon as possible after the death of his relatives. Whereas for families whose wealth is not abundant, the Tiwah ceremony can be carried out together or mutual cooperation by several families or even by one village. This mutual cooperation term in Ngaju is called handep. Tiwah ceremonies generally have duration of seven to forty days. As the biggest sacred ceremony for the Dayak Ngaju people, the holding of the Tiwah ceremony must run perfectly. The time of the Tiwah ceremony is usually held after the rice harvest season, which is around May, June and July. Broadly speaking, the death ceremony in the beliefs of the Dayak Ngaju people can be divided into two namely first, the ceremonies performed after the death of a person until the time of temporary burial and secondly, the Tiwah ceremony itself. Both ceremonies usually have pauses. In the pause or period between the death ceremony after death and the first burial with the Tiwah ceremony, a number of ceremonies are held aimed at feeding and offering spirits. The ceremonies are: Meniti; Mahanjur; Minih; Manampa roared; Manatun; Reply; Tantulak matey. The Tiwah Pre Ceremony is the next post-burial ceremony while the Tiwah ceremony itself.

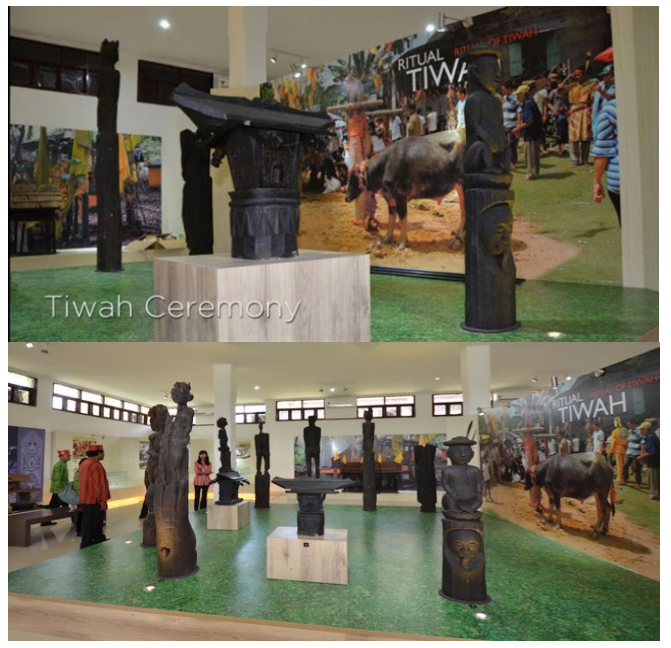

Figure 5 Area of the Dayak death ceremony

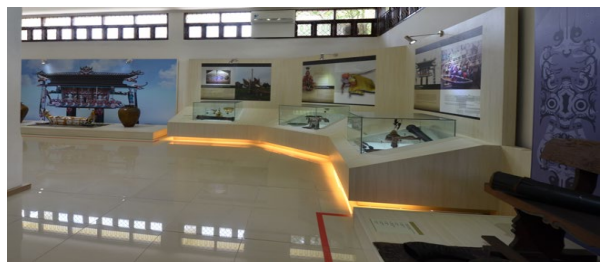

Figure 6 Area of the Dayak death ceremony 


\section{CONCLUSION}

The interior aesthetics of the Balanga Museum is very loaded with rich collections of Dayak history and culture which are strong in color and shape. The Balanga Museum's space theme builds an image of the importance of the meaning of the museum's space through visualization of narrative lines in it which are depicted in lay out planning, material processing, graphics, information, color, lighting, arrangement of objects, and other aesthetic elements by following the historical stages and historical situations of the past with a touch of aesthetic elements in its interior by applying the timeline of the historical life of the Dayak community.Ethnographic museum interior design should prioritize the sense of relaties in interior structuring, the process of deep thinking and interpretation of facts based on the concepts used, developing the concept of structuring with a deep understanding and prioritizing cultural values which constitute the construction of narrative lines presented in the museum collection information

\section{REFERENCES}

[1] Indonesia. Direktorat Musueum. Pedoman Museum Indonesia. Direktorat Museum, Direktorat Jenderal Sejarah dan Purbakala, Departemen Kebudayaan dan Pariwisata. Senayan, Jakarta, 2008

[2] Denzin, Norman K., and Yvonna S. Lincoln. "Hanbook of Qualitative Reseach 2: edisi ketiga." Yogyakarta: Pustaka Pelajar (2011).

[3] Dean, David. Museum exhibition: Theory and practice. Routledge, 2002.

[4] Tjilik, Riwut. "Kalimantan Membangun Alam dan Kebudayaan [Kalimantan Building Nature and Culture]." (2007). 